\title{
The Different Response to an Acid Shock of Two Salmonella Strains Marks Their Resistance to Thermal Treatments
}

OPEN ACCESS

Edited by: Javier Carballo,

University of Vigo, Spain

Reviewed by:

Avelino Alvarez-Ordóñez, Universidad de León, Spain

Rolf Dieter Joerger,

University of Delaware,

United States

*Correspondence: Alfredo Palop

alfredo.palop@upct.es

Specialty section:

This article was submitted to

Food Microbiology,

a section of the journal

Frontiers in Microbiology

Received: 05 April 2021 Accepted: 18 August 2021 Published: 20 September 2021

Citation:

Clemente-Carazo M, Leal J-J, Huertas J-P, Garre A, Palop A and

Periago PM (2021) The Different Response to an Acid Shock of Two

Salmonella Strains Marks Their Resistance to Thermal Treatments.

Front. Microbiol. 12:691248. doi: 10.3389/fmicb.2021.691248

\author{
Marta Clemente-Carazo ${ }^{1}$, José-Juan Leal', Juan-Pablo Huertas ${ }^{1}$, Alberto Garre ${ }^{2}$, \\ Alfredo Palop ${ }^{1 *}$ and Paula M. Periago ${ }^{*}$
}

${ }^{1}$ Departamento Ingeniería Agronómica, Campus de Excelencia Internacional Regional "Campus Mare Nostrum", Instituto de Biotecnología Vegetal, Escuela Técnica Superior de Ingeniería Agronómica, Universidad Politécnica de Cartagena, Cartagena, Spain, ${ }^{2}$ Food Microbiology, Wageningen University \& Research, Wageningen, Netherlands

Microbial cells respond to sub-lethal stresses with several physiological changes to increase their chance of survival. These changes are of high relevance when combined treatments (hurdle technology) are applied during food production, as the cells surviving the first hurdle may have greater resistance to subsequent treatments than untreated cells. In this study, we analyzed if Salmonella develops increased resistance to thermal treatments after the application of an acid shock. We compared the heat resistance of acid-shocked $(\mathrm{pH} 4.5$ achieved with citric acid) Salmonella cells with that of cells maintained at $\mathrm{pH} 7$ (control cells). Thermal treatments were performed between 57.5 and $65^{\circ} \mathrm{C}$. We observed a differential response between the two strains studied. Acid-shocked cells of Salmonella Senftenberg exhibited reduced heat resistance, e.g., for a treatment at $60.0^{\circ} \mathrm{C}$ and pH 7.0 the time required to reduce the population by 3 log cycles was lowered from 10.75 to 1.98 min with respect to control cells. Salmonella Enteritidis showed a different response, with acidshocked cells having similar resistance than untreated cells (the time required to reduce 3 log cycles at $60.0^{\circ} \mathrm{C}$ and $\mathrm{pH} 7.0$ was $0.30 \mathrm{~min}$ for control and 0.31 min for acid-shock cells). Based on results by differential plating (with or without adding the maximum non-inhibitory concentration of $\mathrm{NaCl}$ to the recovery medium), we hypothesize that the differential response between strains can be associated to sub-lethal damage to the cell membrane of $S$. Senftenberg caused by the acid shock. These results provide evidence that different strains of the same species can respond differently to an acid shock and highlight the relevance of cross-resistances for microbial risk assessment.

Keywords: foodborne pathogens, acid shock, pasteurization, cross-resistance, stress adaptation

\section{INTRODUCTION}

Food products can be a potential health hazard for consumers because pathogenic microorganisms may enter the farm-to-fork chain and survive or multiply until consumption (FAO, 2011). Although governmental agencies and other institutions have made intensive efforts toward developing laws and guidelines to ensure food safety, there are still large knowledge gaps in 
the field. Research efforts are needed to better describe the response of foodborne pathogens to the environmental conditions within the food chain. Among them, Salmonella is one of the main safety concerns for the food industry. It causes salmonellosis and is the most frequently detected causative agent of foodborne outbreaks in humans in the European Union (Pires et al., 2019). In 2018, 11,581 outbreak-related human cases of salmonellosis were reported in the European Union; however, this number was lower than the number of total foodborne outbreaks in 2019 (EFSA, 2019, 2021). Salmonella Enteritidis was the serovar most commonly isolated in salmonellosis outbreaks (Manas et al., 2001), accounting for $84.1 \%$ of them in the European Union in 2018 (EFSA, 2019). This serovar is able to grow in a wide range of $\mathrm{NaCl}$ concentrations (between 0 and $4 \%$ ), acid $\mathrm{pH}$ (down to 4.5 ), water activities (minimum 0.93 ), and temperatures (between 10 and $45^{\circ} \mathrm{C}$; Mattick et al., 2000; Álvarez-Ordóñez et al., 2010; Zurera-Cosano et al., 2011). European Union Regulation (EC) 2073/2005 considers Salmonella as a food safety criterium, setting a limit of "not detected in $25 \mathrm{~g}$ or ml" in five samples, for most food categories.

Salmonella can be found in all warm-blooded organisms and the environment, so it can potentially be present in the raw materials used for food production (EFSA, 2019). Hence, one or more steps of food production are usually designed to ensure that the microbial count of this microorganism (and/ or other pathogens) is below a threshold concentration. The most common technology for food preservation is the application of high temperatures. Heat treatments are not only effective to ensure microbiological stability and inhibit alterations caused by pathogens, but it can also lead to enzymatic inactivation (Peng et al., 2017). However, high temperatures can also have a negative impact on the quality of the product, reducing its organoleptic and nutritional attributes (Kilcast and Subramaniam, 2011; González-Tejedor et al., 2017; Peng et al., 2017; Maza et al., 2019). For this reason, industries seek a reduction of the intensity of the processing treatments, delivering safe products with a minimal quality loss (minimally processed products).

The application of alternative technologies to substitute or complement thermal treatments was suggested as a strategy to reduce their impact on food quality several decades ago. Leistner (1978) proposed the so-called "hurdle technology," where mild treatments of a different nature are applied in sequence or simultaneously. According to this approach, food safety can be ensured while reducing the intensity of each individual treatment, improving food quality, and reducing economic cost. On the other hand, due to the combination of several treatments, the hurdle technology requires a deeper knowledge of the process, and a more detailed, science-based understanding of the microbial response to each of the processing treatments (Santos and Silva, 2008). For instance, the application of a treatment that combines high temperature and low $\mathrm{pH}$ requires a description of how the microbial cells respond to both the high temperature and the acidic environment.

The principles of the hurdle technology assume that cells that are able to survive the first "hurdle" will be destroyed by the next "hurdles." However, it is important to take into account that bacterial resistance to stress is affected by the previous history of the cells (Manas and Pagán, 2005; Garre et al., 2019): Sub-lethal damage can alter cellular structures in a reversible or irreversible way, altering their stress resistance (Gilbert, 1984; Hurst, 1984; Yousef and Courtney, 2003). In the particular case of physiological responses to an acid shock, the physiological changes due to stress are denominated acidshock response (ASR; Zhao et al., 1993; Miller and Kaspar, 1994; Leyer et al., 1995), and several articles have reported that ASR can increase the resistance of microbial cells to subsequent stressors (Kwon and Ricke, 1998; Bang et al., 2002; Rishi et al., 2005). This phenomenon can be of high relevance for food production, as demonstrated by ÁlvarezOrdóñez et al. (2012), who observed that, although pathogenic microorganisms were unable to grow in fruit juice, incubation in this medium improved their resistance to subsequent acidic conditions.

Due to the combination of different stresses, food processing based on the hurdle technology can also induce ASR. For instance, it is common for some products to be washed in an acidic solution before they are processed further. Other food products are acidified before being exposed to thermal treatment. Hypothetically, this could induce an ASR in the surviving cells increasing their resistance to a subsequent thermal treatment or other different stresses (Hurst, 1984; Wesche et al., 2009). For that reason, treatments based on the hurdle technology should be designed based on an understanding of not just how the cells respond to each stress, but also to the possible interactions between treatments.

There is plenty of scientific evidence suggesting that the microbial response to stress can vary broadly among different strains of the same microorganism (Koutsoumanis and Aspridou, 2017). For that reason, in this study, we analyzed the heat resistance of acid-shocked cells compared to the one of the cells kept at neutral $\mathrm{pH}$. The study was done by exposing cells to heat after exposure to either $\mathrm{pH} 4.5$ or 7 to elucidate how the ASR may affect the chance of the cells to survive the thermal treatment. Moreover, the experiments were done using two different non-typhoidal Salmonella strains: $S$. Enteritidis (a common reference strain) and $S$. Senftenberg (a strain with exceptionally high thermal resistance, according to Álvarez-Ordóñez et al., 2009). This allowed us to also study the potential effect of biological variability, a topic that is currently of high interest for microbial risk assessment (Committee et al., 2018; Clemente-Carazo et al., 2020; Garre et al., 2020).

\section{MATERIALS AND METHODS}

\section{Bacterial Culture and Media}

The bacteria studied in this research were Salmonella enterica serovar Enteritidis CECT 4300 (type strain) and Salmonella enterica serovar Senftenberg CECT 4565. Both were provided by the Spanish Type Culture Collection (CECT, Valencia, Spain). $S$. Enteritidis was selected because it is usually considered as a reference strain for this species. S. Senftenberg was studied because it is a well-known heat-resistant strain. 
The bacteria were stored at $-80 \pm 2^{\circ} \mathrm{C}(20 \%$ glycerol $)$ until use. Subsequently, for the use of each strain, the bacteria were cultured weekly on trypticase soy agar (TSA, Scharlau Chemie, Barcelona, Spain) supplemented with $0.6 \%$ yeast extract (YE, Scharlau Chemie). The fresh cultures were incubated for $24 \mathrm{~h}$ at $37 \pm 1{ }^{\circ} \mathrm{C}$ in an incubator.

A single colony from a fresh culture plate was transferred to $5 \mathrm{ml}$ of trypticase soy broth (TSB; Scharlau Chemie) supplemented with $0.6 \%$ yeast extract (YE, Scharlau Chemie) and incubated overnight at $37 \pm 1^{\circ} \mathrm{C}$. Flasks with $50 \mathrm{ml}$ of TSBYE were then inoculated with $1 \mathrm{ml}$ of the pre-culture and incubated for $24 \mathrm{~h}$ at $37 \pm 1^{\circ} \mathrm{C}$ with agitation to obtain all cells in stationary phase, which usually are more resistant to different stresses, with a concentration of approx. $10^{9} \mathrm{CFU} / \mathrm{ml}$.

\section{Determination of Minimum pH for Growth}

Sterile TSB (Scharlau Chemie) supplemented with $0.6 \%$ yeast extract (YE, Scharlau Chemie) was prepared at different $\mathrm{pH}$ $(3.75,4.00,4.25,4.50$, and 7.00$)$ by the addition of $1 \mathrm{M}$ citric acid (Panreac, Barcelona, Spain). The $\mathrm{pH}$ was measured after sterilization with a pH meter (Basic20, Crison; Alella, Spain), under strict aseptic conditions, to check there were no changes in the $\mathrm{pH}$. Citric acid was chosen to lower the $\mathrm{pH}$ of the growth medium as it is one of the most common acidulants used to lower the $\mathrm{pH}$ in the food industry.

Then, the growth of both Salmonella serotypes in the acidified TSBYE was determined in a Bioscreen C (Labsystems Helsinki, Finland) at a wavelength of $600 \mathrm{~nm}$. A total of 25 repetitions per $\mathrm{pH}$ value were performed, of which five were left uninoculated and used as negative control. Samples at $\mathrm{pH} 7.00$ were used as positive control.

\section{Induction of the Acid Tolerance Response (Acid Shock)}

A volume of $1 \mathrm{ml}$ of cells in the stationary growth phase $\left(10^{9} \mathrm{CFU} / \mathrm{ml}\right)$ of each serotype was centrifuged at $6,000 \mathrm{~g}$ (MiniSpin ${ }^{\circledR}$ plus, Eppendorf AG, Germany) for $10 \mathrm{~min}$ at $4 \pm 1^{\circ} \mathrm{C}$. Pellets were resuspended in $\mathrm{pH}$ 7.0 TSBYE and centrifuged two more times and resuspended in fresh medium. After the last centrifugation, pellets were resuspended in $\mathrm{pH} 4.5$ TSBYE and were incubated at $37 \pm 1^{\circ} \mathrm{C}$ for $30 \mathrm{~min}$ in an incubator and immediately heat treated.

\section{Determination of the Heat Resistance}

The determination of the heat resistance of the microorganisms was carried out in a Mastia thermoresistometer (Conesa et al., 2009). The heating medium for every experiment was peptone water $[10 \mathrm{~g} / \mathrm{l}$ peptone from casein (Scharlau Chemie) and $5 \mathrm{~g} / \mathrm{l}$ $\mathrm{NaCl}$ (Scharlau Chemie)]. For the experiments that were conducted in acidic media, peptone water was acidified with $1 \mathrm{M}$ citric acid to $\mathrm{pH} 4.5$ and measured with a $\mathrm{pH}$ meter.

The heating medium was inoculated with $0.2 \mathrm{ml}$ of the bacterial suspension (acid shocked and control) with a concentration of approximately $10^{6} \mathrm{CFU} / \mathrm{ml}$. Experiments were performed under isothermal condition. The temperatures and sampling times were set according to the thermal resistance of each microorganism and conditions. For Salmonella Enteritidis, experiments were performed at $52.5,57.5$, and $60.0^{\circ} \mathrm{C}$ at both $\mathrm{pH} 7.0$ and $\mathrm{pH}$ 4.5. For Salmonella Senftenberg, experiments were carried out at higher temperatures $(57.5,60.0,62.5$, and $\left.65.0^{\circ} \mathrm{C}\right)$ at both $\mathrm{pH}$ values $(7.0$ and 4.5$)$ because of the higher thermal resistance of this strain.

Survival counting was performed, from appropriate dilutions in peptone water, in TSAYE or TSAYE $+\mathrm{NaCl}$ (for the determination of sub-lethal damage; see section "Assessment of Sub-Lethal Damage After Treatments"). A minimum of three biologically independent replicate experiments was performed per condition.

\section{Assessment of Sub-Lethal Damage After Treatments}

The concentration of cells with sub-lethal damage after the acid shock was estimated by differential plating in TSAYE and TSAYE supplemented with the maximum non-inhibitory concentration of $\mathrm{NaCl}$ and incubation at $37 \pm 1^{\circ} \mathrm{C}$ for $48 \mathrm{~h}$ (Ray, 1989; Wuytack et al., 2003). The maximum non-inhibitory concentration of $\mathrm{NaCl}$ was determined preparing TSAYE with different percentages of $\mathrm{NaCl}$, from 1 to $5 \%$. Then, cells of both strains of Salmonella spp. were plated on Petri plates and incubated at $37 \pm 1^{\circ} \mathrm{C}$ for $48 \mathrm{~h}$. This concentration resulted in $1 \% \mathrm{NaCl}$ for $\mathrm{S}$. Enteritidis and $3 \%$ for S. Senftenberg.

\section{Data Analysis}

The isothermal inactivation data were analyzed using the Mafart inactivation model (Mafart et al., 2002). This model extends the log-linear inactivation model assuming that the resistance of individual cells is not the same for all them but follows a Weibull distribution. It thus can describe survivor curves with upward or downward curvature. According to Equation (1), in this model, the relationship between the microbial count $(\mathrm{N})$ and the treatment time $(\mathrm{t})$ depends on two parameters: $\delta$ and $\beta$. The former (also called $\delta$-value) corresponds to the scale parameter of the Weibull distribution and can be interpreted as the treatment time required to reduce the microbial count to a $10 \%$ of the initial one, $\mathrm{N}_{0}$. The latter (also called $\beta$-value) is the shape factor of the Weibull distribution and defines the curvature direction of the survivor curves: $\beta>1$ results in survivor curves with downward curvature and $\beta<1$ in upward curvature. For the particular case where $\beta=1$, the Mafart model predicts log-linear inactivation. The primary inactivation model was fitted using the Excel add-in GinaFit (Geeraerd et al., 2005).

$$
\log N=\log N_{0}-\left(\frac{t}{\delta}\right)^{\beta} .
$$

Model fitting was done using the functions included in the bioinactivation $\mathrm{R}$ package (Garre et al., 2018), using a one-step approach based on non-linear regression with the NewtonRaphson algorithm. Initial guesses for the parameter estimates were defined based on preliminary simulations, and several values were tested without observing any relevant impact on parameter estimates. The evaluation of the model fit was based 
on the root mean squared error, a statistical index commonly used in predictive microbiology that quantifies the overall difference between the model fit and the observations, with values closer to one indicating a better correspondence.

Because the $\beta$-value of the survivor curves varied between conditions, in order to compare between them, we calculated the treatment time required to reduce the microbial count 3 $\log$ cycles according to the Weibull model $\left(t_{3 \delta}\right)$. It was calculated as shown in Equation (2).

$$
\mathbf{t}_{\mathbf{n} \delta}=\delta \mathbf{n n}^{1 / \beta}
$$

\section{RESULTS}

Tables 1 and 2 report the parameters of the Weibull model estimated for each isothermal treatment. They confirm the high resistance of $S$. Senftenberg to thermal treatments compared to the reference strain. As an illustration, for the experiments at $60.0^{\circ} \mathrm{C}$ at $\mathrm{pH} 7.0$ without a prior acid shock, a value of $10.75 \mathrm{~min}$ was estimated for $t_{3 \delta}$ for $S$. Senftenberg, whereas a value of $0.30 \mathrm{~min}$ was estimated for $S$. Enteritidis (36 times smaller). This difference in the resistance between both strains is also illustrated in Figure 1, where the survivor curves observed at $60.0^{\circ} \mathrm{C}$ for both microorganisms are depicted. The remaining survivor curves are provided as supplementary material to this article. The inactivation rates are in the order of similar studies found in the literature. Doyle and Mazzotta (2000) reviewed several studies observing that the D-value of $S$. Senftenberg at $60^{\circ} \mathrm{C}$ in laboratory media ranged between 0.62 and $3.06 \mathrm{~min}$. The results are also similar to those by Shah et al. (1991), who observed D-values of Salmonella Enteritidis between $9.98 \mathrm{~min}$ at $54.4^{\circ} \mathrm{C}$ and $0.05 \mathrm{~min}$ at $62.8^{\circ} \mathrm{C}$.

Regarding the curvature direction of the inactivation curves, they differed between strains. S. Senftenberg (Figure 1A and Table 1) presented a tail phenomenon (upward concavity) in all the treatments applied, reflected in $\beta$-values lower than one (for a temperature of $60.0^{\circ} \mathrm{C}$ : $\beta=0.69 \pm 0.08$ for $\mathrm{pH} 4.5$ after acid shock, $\beta=0.52 \pm 0.04$ for $\mathrm{pH} 7.0$ after acid shock, $\beta=0.77 \pm 0.08$ for $\mathrm{pH} 4.5$ without acid shock, and $\beta=0.59 \pm 0.08$ for $\mathrm{pH} 7.0$ without acid shock). On the other hand, $S$. Enteritidis showed $\beta$-values close to one (Figure 1B and Table 2), thus having survivor curves close to log linear (for a temperature of $60.0^{\circ} \mathrm{C}: \beta=1.34 \pm 0.10$ for $\mathrm{pH} 4.5$ after acid shock, $\beta=0.82 \pm 0.15$ for $\mathrm{pH} 7.0$ after acid shock, $\beta=0.98 \pm 0.18$ for $\mathrm{pH} 4.5$ without acid shock, and $\beta=0.83 \pm 0.16$ for $\mathrm{pH} 7.0$ without acid shock).

As expected, the combination of an acidic medium and a heat treatment had a significant impact on the inactivation rate of both strains. As shown in Table 1, S. Senftenberg showed a time for 3 log-reductions at $\mathrm{pH} 4.5$ between two and seven times shorter than at $\mathrm{pH} 7.0\left(\mathrm{t}_{3 \delta}\right.$ values at $\mathrm{pH} 4.5$ of $8.08,2.54,0.44$, and $0.33 \mathrm{~min}$ at $57.5,60.0,62.5$, and $65.0^{\circ} \mathrm{C}$, respectively, compared to $t_{3 \delta}$ values at $\mathrm{pH} 7.0$ of $31.75,10.75$, 3.19 , and $0.77 \mathrm{~min}$ at $57.5,60.0,62.5$, and $65.0^{\circ} \mathrm{C}$, respectively). $S$. Enteritidis was less sensitive to thermal treatment under acidic $\mathrm{pH}$ (Table 2), showing a time to reach 3 log-reductions at $\mathrm{pH} 4.5$ between only two and three times shorter than at $\mathrm{pH} 7.0\left(\mathrm{t}_{3 \delta}\right.$ values at $\mathrm{pH} 4.5$ of $11.22,0.59$, and $0.15 \mathrm{~min}$ at $52.5,57.5$, and $60.0^{\circ} \mathrm{C}$, respectively, compared to $t_{3 \delta}$ values at $\mathrm{pH} 7.0$ of $34.26,0.94$, and $0.30 \mathrm{~min}$ at $52.5,57.5$, and $60.0^{\circ} \mathrm{C}$, respectively; Table 2 ).

The application of an acid shock prior to the thermal treatment had a different impact on the thermal resistance of both strains. For $S$. Senftenberg, the survivor curves at $\mathrm{pH}$ 7.0 after acid shock showed a significantly faster inactivation rate than the one of control cells. The application of the acid shock reduced $\mathrm{t}_{3 \delta}$ at $60^{\circ} \mathrm{C}$ from $10.75 \mathrm{~min}$ for control cells to $1.98 \mathrm{~min}$ for acid-shocked cells. Notably, the value of $t_{3 \delta}$ observed for acid-shocked cells at $\mathrm{pH} 7.0$ (1.98 min) was about the same as that observed at $\mathrm{pH} 4.5$ without any previous acid shock (2.54 min). This similarity between inactivation under both conditions is clearly illustrated in Figure 1A. Therefore, the application of an acid shock prior to a treatment at $\mathrm{pH}$

TABLE 1 | Parameters of the Weibull model estimated from the survival curves of $S$. Senftenberg heat treated in peptone water without a prior acid shock (control cells) and after an acid shock at $\mathrm{pH} 4.5$.

\begin{tabular}{|c|c|c|c|c|c|c|}
\hline & $\mathrm{pH}$ & Temperature $\left({ }^{\circ} \mathrm{C}\right)$ & $\delta$ (min) & $\beta(\cdot)$ & $t_{3 \delta}(\min )$ & RMSE (log CFU/ml) \\
\hline \multirow[t]{8}{*}{ Control cells } & 4.5 & 57.5 & $1.53 \pm 0.55$ & $0.66 \pm 0.12$ & 8.08 & 0.31 \\
\hline & & 60.0 & $0.61 \pm 0.12$ & $0.77 \pm 0.08$ & 2.54 & 0.27 \\
\hline & & 62.5 & $0.04 \pm 0.01$ & $0.46 \pm 0.04$ & 0.44 & 0.29 \\
\hline & & 65.0 & $0.11 \pm 0.03$ & $1.01 \pm 0.16$ & 0.33 & 0.45 \\
\hline & 7.0 & 57.5 & $6.61 \pm 2.61$ & $0.70 \pm 0.15$ & 31.75 & 0.32 \\
\hline & & 60.0 & $1.67 \pm 0.51$ & $0.59 \pm 0.08$ & 10.75 & 0.27 \\
\hline & & 62.5 & $0.37 \pm 0.08$ & $0.51 \pm 0.04$ & 3.19 & 0.17 \\
\hline & & 65.0 & $0.16 \pm 0.05$ & $0.70 \pm 0.11$ & 0.77 & 0.33 \\
\hline \multirow{8}{*}{$\begin{array}{l}\text { Acid-shocked } \\
\text { cells }\end{array}$} & 4.5 & 57.5 & $0.65 \pm 0.15$ & $0.55 \pm 0.04$ & 4.79 & 0.21 \\
\hline & & 60.0 & $0.33 \pm 0.09$ & $0.69 \pm 0.08$ & 1.62 & 0.31 \\
\hline & & 62.5 & $0.01 \pm 0.01$ & $0.30 \pm 0.04$ & 0.39 & 0.31 \\
\hline & & 65.0 & $0.05 \pm 0.01$ & $0.73 \pm 0.09$ & 0.23 & 0.23 \\
\hline & 7.0 & 57.5 & $1.42 \pm 0.29$ & $0.60 \pm 0.06$ & 8.86 & 0.17 \\
\hline & & 60.0 & $0.24 \pm 0.05$ & $0.52 \pm 0.04$ & 1.98 & 0.20 \\
\hline & & 62.5 & $0.08 \pm 0.03$ & $0.47 \pm 0.05$ & 0.83 & 0.26 \\
\hline & & 65.0 & $0.0016 \pm 0.0013$ & $0.24 \pm 0.04$ & 0.16 & 0.16 \\
\hline
\end{tabular}


TABLE 2 I Parameters of the Weibull model estimated from the survival curves of S. Enteritidis heat treated in peptone water without a prior acid shock (control cells) and after an acid shock at $\mathrm{pH} 4.5$.

\begin{tabular}{|c|c|c|c|c|c|c|}
\hline & $\mathrm{pH}$ & Temperature $\left({ }^{\circ} \mathrm{C}\right)$ & $\delta$ (min) & $\beta(\cdot)$ & $t_{3 \delta}(\mathrm{min})$ & RMSE (log CFU/ml) \\
\hline \multirow[t]{6}{*}{ Control cells } & 4.5 & 52.5 & $2.44 \pm 0.43$ & $0.72 \pm 0.05$ & 11.22 & 0.26 \\
\hline & & 57.5 & $0.14 \pm 0.03$ & $0.76 \pm 0.08$ & 0.59 & 0.24 \\
\hline & & 60.0 & $0.05 \pm 0.01$ & $0.98 \pm 0.18$ & 0.15 & 0.38 \\
\hline & 7.0 & 52.5 & $6.32 \pm 1.84$ & $0.65 \pm 0.09$ & 34.26 & 0.28 \\
\hline & & 57.5 & $0.16 \pm 0.04$ & $0.62 \pm 0.07$ & 0.94 & 0.28 \\
\hline & & 60.0 & $0.08 \pm 0.02$ & $0.83 \pm 0.16$ & 0.30 & 0.29 \\
\hline \multirow{6}{*}{$\begin{array}{l}\text { Acid-shocked } \\
\text { cells }\end{array}$} & 4.5 & 52.5 & $5.82 \pm 2.12$ & $0.76 \pm 0.14$ & 24.70 & 0.43 \\
\hline & & 57.5 & $0.36 \pm 0.04$ & $0.98 \pm 0.07$ & 1.10 & 0.19 \\
\hline & & 60.0 & $0.11 \pm 0.01$ & $1.34 \pm 0.10$ & 0.25 & 0.13 \\
\hline & 7.0 & 52.5 & $18.9 \pm 0.6$ & $2.15 \pm 0.12$ & 31.52 & 0.18 \\
\hline & & 57.5 & $0.34 \pm 0.05$ & $1.24 \pm 0.18$ & 0.82 & 0.27 \\
\hline & & 60.0 & $0.08 \pm 0.02$ & $0.82 \pm 0.15$ & 0.31 & 0.27 \\
\hline
\end{tabular}

7 had a similar impact on the inactivation kinetics than a combined thermal treatment at $\mathrm{pH}$ 4.5. Regarding the effect of an acid shock before a thermal treatment at $\mathrm{pH} 4.5$ for $S$. Senftenberg, although the stress resistance was reduced, the magnitude of this reduction was not as large as for the treatments at $\mathrm{pH}$ 7. The value of $\mathrm{t}_{3 \delta}$ was reduced from 2.54 to $1.62 \mathrm{~min}$ at $60^{\circ} \mathrm{C}$. Similar results were obtained at all other temperatures tested (Table 1). In summary, the application of an acid shock to $S$. Senftenberg reduced its thermal resistance. Indeed, the inactivation kinetics of acid-shocked cells at a $\mathrm{pH}$ of 7.0 was similar to the one of control cells at $\mathrm{pH} 4.5$. For treatments with a $\mathrm{pH}$ of 4.5 , the thermal resistance of acid-shocked cells was further reduced.

Conversely, $S$. Enteritidis had a very different response to the application of an acid shock. As shown in Table 2, acidshocked cells of $S$. Enteritidis had a resistance to the thermal treatment in both acidic and neutral media equivalent to the one observed for control cells at $\mathrm{pH} 7\left(\mathrm{t}_{3 \delta}\right.$ at $60.0^{\circ} \mathrm{C}$ of $0.30 \mathrm{~min}$ for control cells at $\mathrm{pH} 7.0,0.31 \mathrm{~min}$ for acid-shocked cells treated at $\mathrm{pH} 7.0$, and $0.25 \mathrm{~min}$ for acid-shocked cells treated at $\mathrm{pH} 4.5$ ). These similarities are illustrated in Figure 1B, where the survivor curves obtained at $60.0^{\circ} \mathrm{C}$ are illustrated. This plot shows how the survivor curves for acid-shocked cells for a treatment $\mathrm{pH}$ of 4.5 and 7.0 are about the same as the one observed for control cells for a treatment $\mathrm{pH}$ of 7.0. This result can indicate that the acid shock causes an ASR that induces an increase in the thermal resistance of $S$. Enteritidis cells, making them insensitive to changes in the acidity of the heating medium in subsequent treatments.

The data obtained using differential plating with $\mathrm{NaCl}$ provide further evidence to support the hypothesis that ASR is responsible for the different results observed between the two strains. Figure 2 compares the microbial counts observed in TSAYE and TSAYE supplemented with $\mathrm{NaCl}$. For $S$. Senftenberg, we observed microbial counts between 1 and $2 \log \mathrm{CFU} / \mathrm{mL}$ lower in TSAYE $+\mathrm{NaCl}$ than in TSAYE at both $\mathrm{pH}$ levels (7.0 and 4.5). This is an indicator of sub-lethal damage in the microbial cells that could justify our results, where acid-shocked cells had a lower heat resistance than control cells (Figure 2A). On the other hand, we did not observe any difference between the microbial counts recovered in TSAYE and TSAYE $+\mathrm{NaCl}$ for $S$. Enteritidis, indicating the absence of sub-lethal damage for this strain. This could enable the development of ASR of the cells that could induce an increased thermal resistance, justifying our results (Figure 2B).

\section{DISCUSSION}

The addition of chemicals (e.g., salts, acids, and oxidizers) or the application of physical treatments (e.g., heat and pressures) for food preservation induce a variety of environmental stresses that can inactivate pathogenic and spoilage microorganisms present in the food product. However, current processing treatments are not flawless, evidenced by the fact that a number of foods with an acidic $\mathrm{pH}$ have been implicated in outbreaks. Indeed, some studies have questioned the effect of acid on the effective control of some microorganisms (Parish, 1997; Evans et al., 1999; Rodriguez-Romo et al., 2005; Vojdani et al., 2008; Jain et al., 2009). Furthermore, previous studies have demonstrated that acidic conditions may improve the resistance of some strains of Salmonella spp. An example is the work by Perez et al. (2010), who showed that incubation in acidic condition led to an increase in the survival of $S$. Enteritidis in gastrointestinal liquids, due to prior adaptation to an acidic $\mathrm{pH}$. The ability of Salmonella spp. to survive this type of stresses and their presence in a wide variety of foods makes it a high-risk pathogen (Rychlik and Barrow, 2005). As a result, an accurate risk assessment for this microorganism requires to understand the physiological state of the cells and the potential for a stress adaptation (Álvarez-Ordóñez et al., 2013). This is especially relevant as several strains of Salmonella can develop an increased stress resistance when exposed to acidic conditions, including $S$. Enteritidis and S. Senftenberg (Hsin-Yi and Chou, 2001; Greenacre et al., 2003; Koutsoumanis et al., 2003; Koutsoumanis and Sofos, 2004; Stopforth et al., 2007; Skandamis et al., 2009; Álvarez-Ordóñez et al., 2012).

In the current study, we have observed a differential response in two Salmonella strains when exposed to an acid shock. The acid-shocked $S$. Senftenberg cells became more sensitive to 

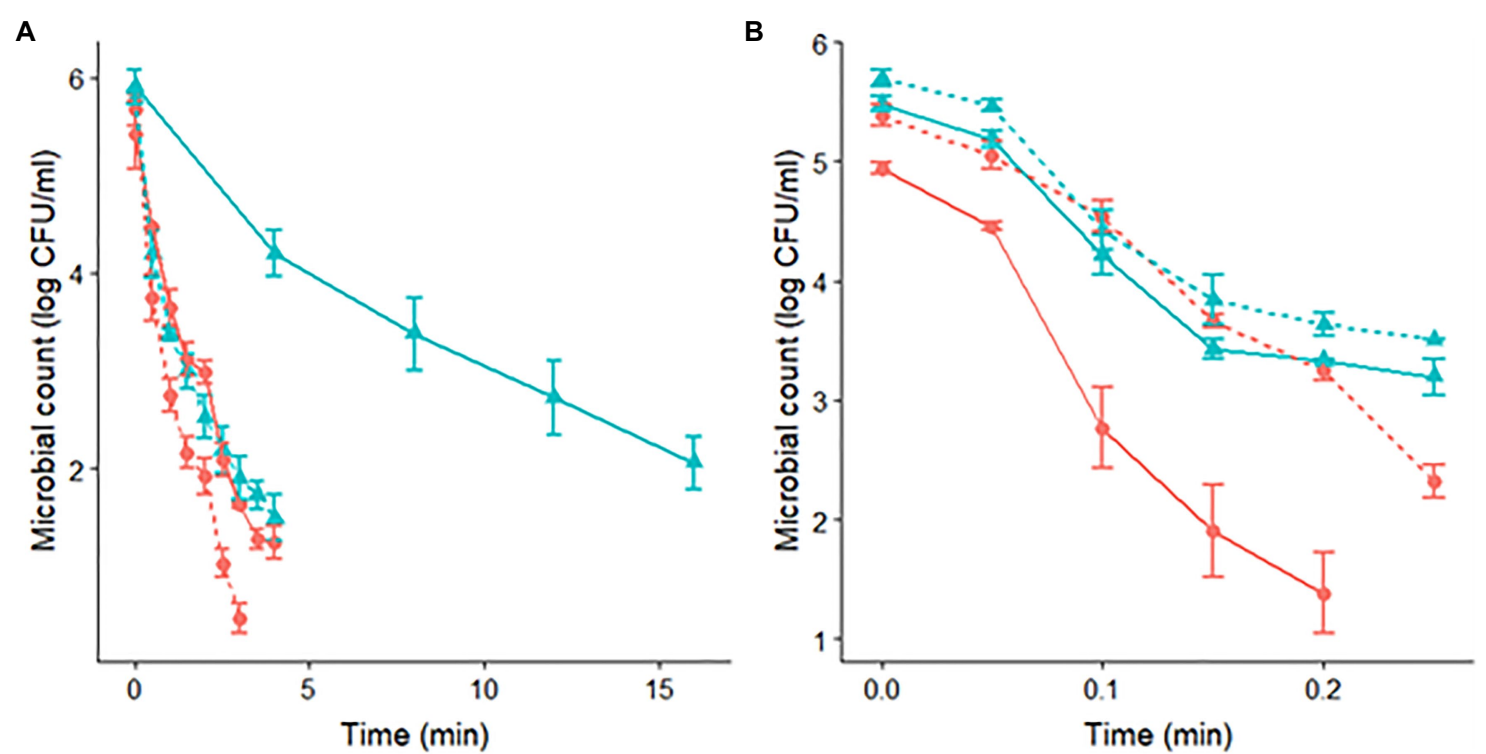

FIGURE 1 | Survivor curves of S. Senftenberg (A) and S. Enteritidis (B) during isothermal treatments at $60^{\circ} \mathrm{C}$ in peptone water. The $\mathrm{pH}$ of the heating media was set at pH 7.0 ( $(\Delta)$ and pH $4.5($ (O). Experiments were made for cells with a previous acid shock (dashed lines) and control cells, without acid shock (continuous lines).
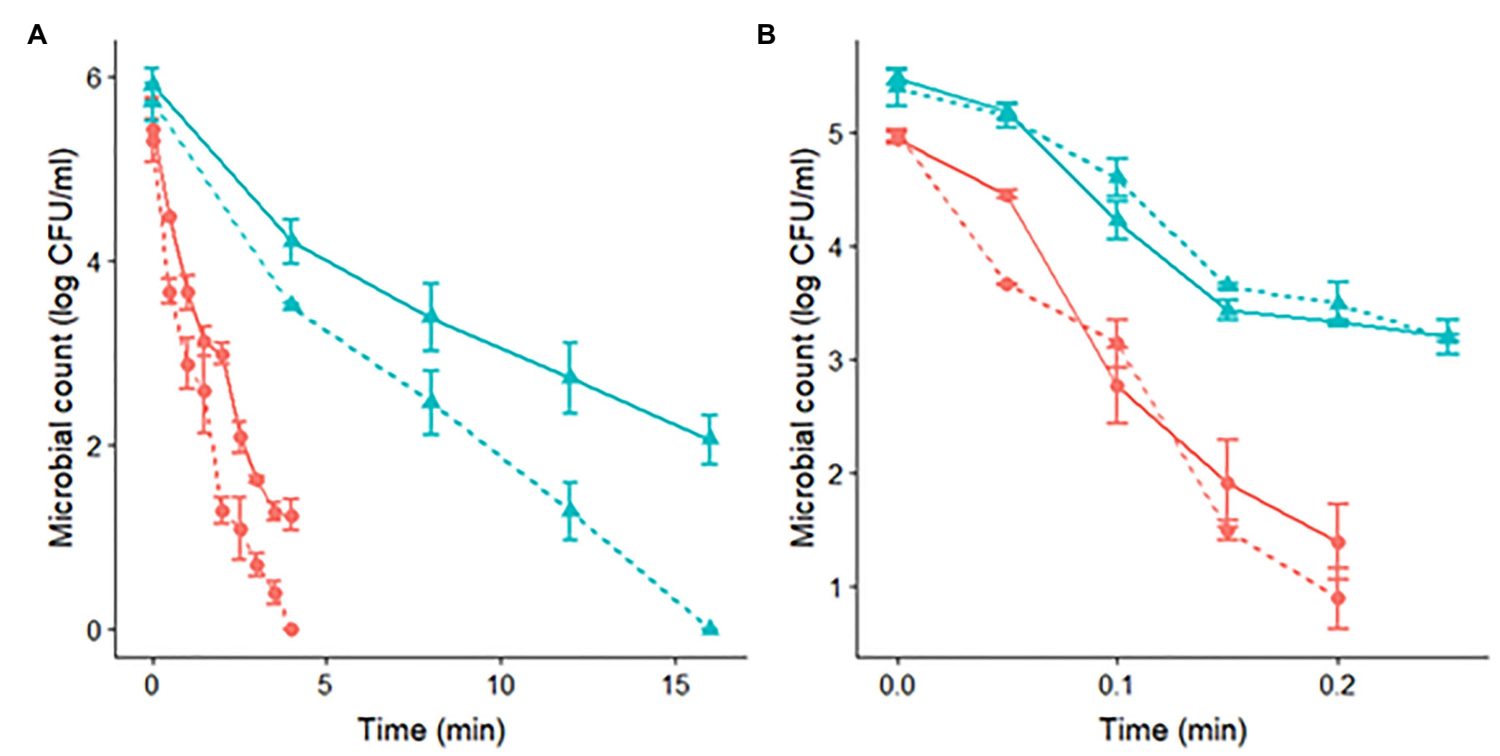

FIGURE 2 | Survivor curves of S. Senftenberg (A) and S. Enteritidis (B) during isothermal treatments at $60^{\circ} \mathrm{C}$ in peptone water and recovered in TSAYE (continuous lines) and TSAYE with $\mathrm{NaCl}$ (dashed lines) for experiments performed at pH $7.0(\Lambda)$ and pH $4.5(\bullet)$.

the thermal treatment, whereas $S$. Enteritidis showed the opposite response. For treatments at $\mathrm{pH} 7$, the resistance of acid-shocked cells was practically the same as the one of control cells. Moreover, acid-shocked cells of $S$. Enteritidis were practically insensitive to changes in the $\mathrm{pH}$ of the heating medium in our experiments (practically the same $t_{3 \delta}$ values at $\mathrm{pH} 7$ and 4.5). These results are in-line with those by Malheiros et al. (2009), who observed that at temperatures of 52.0 and $56.0^{\circ} \mathrm{C} S$. Enteritidis was able to survive, showing higher adaptation capabilities than other serovars of this species in a heating medium in the presence of glucose at $\mathrm{pH} 4.5$. A similar physiological response (albeit for a different microorganism) was reported by Haberbeck et al. (2017). In their study, they observed that 48 Escherichia coli strains were able to adapt after incubation at $\mathrm{pH} 5.5$, increasing their thermal resistance to treatments at $58.0^{\circ} \mathrm{C}$. Not all the studies confirm these results, since other authors showed an increased sensitivity to heat when exposed to low $\mathrm{pH}$ in this same pathogen of 
E. coli (Lee and Kang, 2009; Parry-Hanson et al., 2010). Our empirical results demonstrate that very different responses can be observed in the ability of different strains of a microorganism to develop an increased stress resistance after being subjected to an acid shock.

Conversely to $S$. Enteritidis, we observed that for $S$. Senftenberg the application of an acid shock increased the sensitivity of the bacteria to posterior thermal treatments. Based on our observations using differential plating, this result could be attributed to sub-lethal damage in the cytoplasmic membrane of $S$. Senftenberg cells. This result is in disagreement with those reported by Álvarez-Ordóñez et al. (2009), who observed that acid-adapted cells of $S$. Senftenberg would develop increased stress resistance. However, these authors allowed the growth of the cells in acidified media for a long time, while we applied a short acid shock. They also used food matrices as heating media (orange juice and apple juice), whereas in our study we used laboratory media. There is empirical evidence showing that food matrices can have a protective effect on microbial cells (Maté et al., 2017; Verheyen et al., 2019, 2020). Hence, it is a plausible hypothesis that the food matrix shall also influence the development of increased stress resistance.

During the last decades, the application of modern technologies (e.g., genomics) have shed light on the genes involved in the microbial response to stress, and the molecular mechanisms that intercede in the cellular response to acidic conditions. Due to low $\mathrm{pH}$ environments, protons are expelled from the cytoplasm to regulate $\mathrm{pH}$ levels within the cell. This is carried out with potassium-proton and sodium-proton antiporter pumps, keeping the intracellular $\mathrm{pH}$ constant (Foster, 2000). Previous studies have also shown that through the synthesis of acid-shock proteins and regulatory proteins, the cell is able to avoid or repair the damage caused by the acid stress. These molecular mechanisms can explain the empirical evidence supporting the hypothesis that microbial cells are able to recover from the damage caused by an acid stress (Audia et al., 2001).

\section{CONCLUSION}

Our results demonstrate that the response to an acid shock of Salmonella cells depends very much on the strains of this species. The application of an acid shock strongly reduced the heat resistance of $S$. Senftenberg, whereas the same shock

\section{REFERENCES}

Álvarez-Ordóñez, A., Fernández, A., Bernardo, A., and López, M. (2009). A comparative study of thermal and acid inactivation kinetics in fruit juices of salmonella enterica serovar Typhimurium and salmonella enterica serovar Senftenberg grown at acidic conditions. Foodborne Pathog. Dis. 6, 1147-1155. doi: $10.1089 / \mathrm{fpd} .2009 .0313$

Álvarez-Ordóñez, A., Halisch, J., and Prieto, M. (2010). Changes in Fourier transform infrared spectra of salmonella enterica serovars Typhimurium and Enteritidis after adaptation to stressful growth conditions. Int. J. Food Microbiol. 142, 97-105. doi: 10.1016/j.ijfoodmicro.2010.06.008 induced a stress response in $S$. Enteritidis, increasing its heat resistance. These responses may probably be representative of extreme behaviors within strains of this species and should be taken into account when applying an acid wash or even acidifying food products prior to exposing them to a thermal preservation treatment. This result can also help advance risk assessment, reducing the uncertainty associated to the microbial response in acidic food products.

\section{DATA AVAILABILITY STATEMENT}

The original contributions presented in the study are included in the article/Supplementary Material, further inquiries can be directed to the corresponding author.

\section{AUTHOR CONTRIBUTIONS}

MC-C, J-JL, J-PH, AG, AP, and PP: conceptualization. MC-C and AG: formal analysis. MC-C and JJL: investigation. MC-C: writing-original draft preparation. $\mathrm{MC}-\mathrm{C}, \mathrm{AG}, \mathrm{AP}$, and $\mathrm{PP}$ : writing-review and editing. J-PH, AG, AP, and PP: supervision. All authors have read and agreed to the published version of the manuscript.

\section{FUNDING}

This research was funded by the Ministry of Science, Innovation and Universities of The Spanish Government and European Regional Development Fund (ERDF), grant numbers AGL2017-86840-C2-1-R and PID2020-116318RB-C32. Alberto Garre was supported by a postdoctoral grant from the Fundacion Séneca grant number $20900 / \mathrm{PD} / 18$ and by the European Union's Horizon 2020 Research and Innovation Programme under the Marie Sklodowska-Curie grant number 844423 (FANTASTICAL).

\section{SUPPLEMENTARY MATERIAL}

The Supplementary Material for this article can be found online at: https://www.frontiersin.org/articles/10.3389/fmicb. 2021.691248/full\#supplementary-material

Álvarez-Ordóñez, A., Prieto, M., Bernardo, A., Hill, C., and López, M. (2012) The acid tolerance response of salmonella spp.: an adaptive strategy to survive in stressful environments prevailing in foods and the host. Food res. Int. 45, 482-492. doi: 10.1016/j.foodres.2011.04.002

Álvarez-Ordóñez, A., Valdés, L., Bernardo, A., Prieto, M., and López, M. (2013). Survival of acid adapted and non-acid adapted salmonella Typhimurium in pasteurized orange juice and yogurt under different storage temperatures. Food Sci. Technol. Int. 19, 407-414. doi: 10.1177/ 1082013212455343

Audia, J. P., Webb, C. C., and Foster, J. W. (2001). Breaking through the acid barrier: an orchestrated response to proton stress by enteric bacteria. Int. J. Med. Microbiol. 291, 97-106. doi: 10.1078/1438-4221-00106 
Bang, I. S., Audia, J. P., Park, Y. K., and Foster, J. W. (2002). Autoinduction of the ompR response regulator by acid shock and control of the salmonella enterica acid tolerance response. Mol. Microbiol. 44, 1235-1250. doi: 10.1046/j. 1365-2958.2002.02937.x

Clemente-Carazo, M., Cebrián, G., Garre, A., and Palop, A. (2020). Variability in the heat resistance of listeria monocytogenes under dynamic conditions can be more relevant than that evidenced by isothermal treatments. Food Res. Int. 137:109538. doi: 10.1016/j.foodres.2020.109538

Committee, E. S., Benford, D., Halldorsson, T., Jeger, M. J., Knutsen, H. K., More, S., et al. (2018). Guidance on uncertainty analysis in scientific assessments. EFSA J. 16:e05123. doi: 10.2903/j.efsa.2018.5123

Conesa, R., Andreu, S., Fernández, P. S., Esnoz, A., and Palop, A. (2009). Nonisothermal heat resistance determinations with the thermoresistometer Mastia. J. Appl. Microbiol. 107, 506-513. doi: 10.1111/j.1365-2672.2009.04236.x

Doyle, M. E., and Mazzotta, A. S. (2000). Review of studies on the thermal resistance of salmonellae. J. Food Prot. 63, 779-795. doi: 10.4315/0362-028X-63.6.779

EFSA (2021). The European Union one health 2019 Zoonoses report. EFSA J. 19:e06406. doi: 10.2903/j.efsa.2021.6802

EFSA (2019). The European Union one health 2018 Zoonoses report. EFSA J. 17:e05926. doi: 10.2903/j.efsa.2019.5926

Evans, M. R., Salmon, R. L., Nehaul, L., Mably, S., Wafford, L., Nolan-Farrell, M. Z., et al. (1999). An outbreak of salmonella Typhimurium DT170 associated with kebab meat and yoghurt relish. Epidemiol. Infect. 122, 377-383. doi: $10.1017 /$ S0950268899002253

FAO (2011). Global food losses and food waste-extent, causes and prevention. Available at: http://www.fao.org/docrep/014/mb060e/mb060e00.pdf (Accessed April 2, 2020).

Foster, J. W. (2000). "Microbial responses to acid stress," in Bacterial Stress Responses. eds. G. Storz, and R. Hengge-Aronis (Washington, DC: ASM Press), 99-115.

Garre, A., Clemente-Carazo, M., Fernández, P. S., Lindqvist, R., and Egea, J. A. (2018). Bioinactivation FE: A free web application for modelling isothermal and dynamic microbial inactivation. Food Res. Int. 112, 353-360. doi: 10.1016/j. foodres.2018.06.057

Garre, A., González-Tejedor, G. A., Aznar, A., Fernández, P. S., and Egea, J. A. (2019). Mathematical modelling of the stress resistance induced in listeria monocytogenes during dynamic, mild heat treatments. Food Microbiol. 84:103238. doi: 10.1016/j.fm.2019.06.002

Garre, A., Zwietering, M. H., and den Besten, H. M. (2020). Multilevel modelling as a tool to include variability and uncertainty in quantitative microbiology and risk assessment. Thermal inactivation of listeria monocytogenes as proof of concept. Food Res. Int. 137:109374. doi: 10.1016/j. foodres.2020.109374

Geeraerd, A. H., Valdramidis, V. P., and Van Impe, J. F. (2005). GInaFiT, a freeware tool to assess non-log-linear microbial survivor curves. Int. J. Food Microbiol. 102, 95-105. doi: 10.1016/j.ijfoodmicro.2004.11.038

Gilbert, P. (1984). "The revival of micro-organisms sublethally injured by chemical inhibitors," in The Revival of Injured Microbes. eds. M. H. E. Andrews and A. D. Russell (London, UK: Academic Press), 175-197.

González-Tejedor, G. A., Martínez-Hernández, G. B., Garre, A., Egea, J. A., Fernández, P. S., and Artés-Hernández, F. (2017). Quality changes and shelflife prediction of a fresh fruit and vegetable purple smoothie. Food Bioprocess Technol. 10, 1892-1904. doi: 10.1007/s11947-017-1965-5

Greenacre, E. J., Brocklehurst, T. F., Waspe, C. R., Wilson, D. R., and Wilson, P. D. G. (2003). Salmonella enterica serovar Typhimurium and listeria monocytogenes acid tolerance response induced by organic acids at $20 \mathrm{C}$ : optimization and modeling. Appl Env. Microbiol. 69, 3945-3951. doi: 10.1128/ AEM.69.7.3945-3951.2003

Haberbeck, L. U., Wang, X., Michiels, C., Devlieghere, F., Uyttendaele, M., and Geeraerd, A. H. (2017). Cross-protection between controlled acid-adaptation and thermal inactivation for 48 Escherichia coli strains. Int. J. Food Microbiol. 241, 206-214. doi: 10.1016/j.ijfoodmicro.2016.10.006

Hsin-Yi, C., and Chou, C.-C. (2001). Acid adaptation and temperature effect on the survival of Escherichia coli O157: H7 in acidic fruit juice and lactic fermented milk product. Int. J. Food Microbiol. 70, 189-195. doi: 10.1016/ s0168-1605(01)00538-4

Hurst, A. (1984). "Revival of vegetative bacteria after sublethal heating," in The Revival of Injured Microbes. eds. M. H. E. Andrews and A. D. Russell (London, UK: Academic Press), 77-103.
Jain, S., Bidol, S. A., Austin, J. L., Berl, E., Elson, F., Williams, M. L., et al. (2009). Multistate outbreak of salmonella Typhimurium and Saintpaul infections associated with unpasteurized orange juice-United States, 2005. Clin. Infect. Dis. 48, 1065-1071. doi: 10.1086/597397

Kilcast, D., and Subramaniam, P. (2011). Food and Beverage Stability and Shelf Life. Netherlands: Elsevier.

Koutsoumanis, K. P., and Aspridou, Z. (2017). Individual cell heterogeneity in predictive food microbiology: challenges in predicting a "noisy" world. Int. J. Food Microbiol. 240, 3-10. doi: 10.1016/j.ijfoodmicro.2016.06.021

Koutsoumanis, K. P., Kendall, P. A., and Sofos, J. N. (2003). Effect of food processing-related stresses on acid tolerance of listeria monocytogenes. Appl. Env. Microbiol 69, 7514-7516. doi: 10.1128/AEM.69.12.7514-7516.2003

Koutsoumanis, K. P., and Sofos, J. N. (2004). Comparative acid stress response of listeria monocytogenes, Escherichia coli O157: H7 and salmonella Typhimurium after habituation at different $\mathrm{pH}$ conditions. Lett. Appl. Microbiol. 38, 321-326. doi: 10.1111/j.1472-765X.2004.01491.x

Kwon, Y. M., and Ricke, S. C. (1998). Induction of acid resistance of salmonella Typhimurium by exposure to short-chain fatty acids. Appl. Environ. Microbiol. 64, 3458-3463. doi: 10.1128/AEM.64.9.3458-3463.1998

Lee, S.-Y., and Kang, D.-H. (2009). Combined effects of heat, acetic acid, and salt for inactivating Escherichia coli O157: H7 in laboratory media. Food Control 20, 1006-1012. doi: 10.1016/j.foodcont.2008.12.002

Leistner, L. (1978). "Hurdle effect and energy saving," in Food Quality and Nutrition. ed. W. K. Downey (London, UK: Applied Science Publishers), 553-557.

Leyer, G. J., Wang, L.-L., and Johnson, E. A. (1995). Acid adaptation of Escherichia coli O157: H7 increases survival in acidic foods. Appl. Environ. Microbiol. 61, 3752-3755.

Mafart, P., Couvert, O., Gaillard, S., and Leguérinel, I. (2002). On calculating sterility in thermal preservation methods: application of the Weibull frequency distribution model. Int. J. Food Microbiol. 72, 107-113. doi: 10.1016/ S0168-1605(01)00624-9

Malheiros, P. S., Brandelli, A., Noreña, C. P. Z., and Tondo, E. C. (2009). Acid and thermal resistance of a salmonella Enteritidis strain involved in several foodborne outbreaks. J. Food Saf. 29, 302-317. doi: 10.1111/j.1745-4565.2009.00158.x

Manas, P., and Pagán, R. (2005). Microbial inactivation by new technologies of food preservation. J. Appl. Microbiol. 98, 1387-1399. doi: 10.1111/j.1365-2672.2005.02561.x

Manas, P., Pagan, R., Leguérinel, I., Condon, S., Mafart, P., and Sala, F. (2001). Effect of sodium chloride concentration on the heat resistance and recovery of salmonella Typhimurium. Int. J. Food Microbiol. 63, 209-216. doi: 10.1016/ s0168-1605(00)00423-2

Maté, J., Periago, P. M., Ros-Chumillas, M., Grullón, C., Huertas, J. P., and Palop, A. (2017). Fat and fibre interfere with the dramatic effect that nanoemulsified D-limonene has on the heat resistance of listeria monocytogenes. Food Microbiol. 62, 270-274. doi: 10.1016/j.fm.2016.10.031

Mattick, K. L., Jørgensen, F., Legan, J. D., Cole, M. B., Porter, J., Lappin-Scott, H. M., et al. (2000). Survival and filamentation of salmonella enterica serovar Enteritidis pt4 and salmonella enterica serovar Typhimurium dt104 at low water activity. Appl Env. Microbiol 66, 1274-1279. doi: 10.1128/ AEM.66.4.1274-1279.2000

Maza, M. A., Martínez, J. M., Hernández-Orte, P., Cebrián, G., Sánchez-Gimeno, A. C., Álvarez, I., et al. (2019). Influence of pulsed electric fields on aroma and polyphenolic compounds of Garnacha wine. Food Bioprod. Process. 116, 249-257. doi: 10.1016/j.fbp.2019.06.005

Miller, L. G., and Kaspar, C. W. (1994). Escherichia coli O157: H7 acid tolerance and survival in apple cider. J. Food Prot. 57, 460-464. doi: 10.4315/0362-028X-57.6.460

Parish, M. E. (1997). Public health and nonpasteurized fruit juices. Crit. Rev. Microbiol. 23, 109-119.

Parry-Hanson, A. A., Jooste, P. J., and Buys, E. M. (2010). Relative gene expression in acid-adapted Escherichia coli O157: H7 during lactoperoxidase and lactic acid challenge in Tryptone soy broth. Microbiol. Res. 165, 546556. doi: 10.1016/j.micres.2009.11.003

Peng, J., Tang, J., Barrett, D. M., Sablani, S. S., Anderson, N., and Powers, J. R. (2017). Thermal pasteurization of ready-to-eat foods and vegetables: critical factors for process design and effects on quality. Crit. Rev. Food Sci. Nutr. 57, 2970-2995. doi: 10.1080/10408398.2015.1082126

Perez, K. J., Ceccon, R. V., Da Silva Malheiros, P., Jong, E. V., and Cesar Tondo, E. (2010). Influence of acid adaptation on the survival of salmonella 
Enteritidis and salmonella Typhimurium in simulated gastric fluid and in Rattus norvegicus intestine infection. J. Food Saf. 30, 398-414. doi: 10.1111/j. 1745-4565.2010.00215.x

Pires, S. M., Jakobsen, L. S., Ellis-Iversen, J., Pessoa, J., and Ethelberg, S. (2019). Burden of disease estimates of seven pathogens commonly transmitted Through foods in Denmark, 2017. Foodborne Pathog. Dis. 17, 322-339. doi: 10.1089/fpd.2019.2705

Ray, B. (ed.) (1989). "Enumeration of injured indicator bacteria from foods," in Injured Index and Pathogenic Bacteria. (Boca Raton, FL: CRC Press), 9-54.

Rishi, P., Pathak, S., and Ricke, S. C. (2005). Short chain fatty acids influence virulence properties of salmonella enterica serovar Typhimurium. J. Environ. Sci. Health Part B 40, 645-657. doi: 10.1081/PFC-200061576

Rodriguez-Romo, L. A., and Yousef, A. (2005). "Cross-protective effects of bacterial stress," in Understanding Pathogen Behaviour. ed. M. Griffiths (Camdridge: Elsevier), 128-151.

Rychlik, I., and Barrow, P. A. (2005). Salmonella stress management and its relevance to behaviour during intestinal colonisation and infection. FEMS Microbiol. Rev. 29, 1021-1040. doi: 10.1016/j.femsre.2005.03.005

Santos, P. H. S., and Silva, M. A. (2008). Retention of vitamin C in drying processes of fruits and vegetables-A review. Dry. Technol. 26, 1421-1437. doi: 10.1080/07373930802458911

Shah, D. B., Bradshaw, J. G., and Peeler, J. T. (1991). Thermal resistance of egg-associated epidemic strains of salmonella Enteritidis. J. Food Sci. 56, 391-393.

Skandamis, P. N., Stopforth, J. D., Yoon, Y., Kendall, P. A., and Sofos, J. N. (2009). Heat and acid tolerance responses of listeria monocytogenes as affected by sequential exposure to hurdles during growth. J. Food Prot. 72, 1412-1418. doi: 10.4315/0362-028X-72.7.1412

Stopforth, J. D., Skandamis, P. N., Geornaras, I., and Sofos, J. N. (2007). Acid tolerance of acid-adapted and nonacid-adapted Escherichia coli O157: H7 strains in beef decontamination runoff fluids or on beef tissue. Food Microbiol. 24, 530-538. doi: 10.1016/j.fm.2006.05.007

Verheyen, D., Baka, M., Akkermans, S., Skåra, T., and Van Impe, J. F. (2019). Effect of microstructure and initial cell conditions on thermal inactivation kinetics and sublethal injury of listeria monocytogenes in fish-based food model systems. Food Microbiol. 84:103267. doi: 10.1016/j. fm.2019.103267

Verheyen, D., Govaert, M., Seow, T. K., Ruvina, J., Mukherjee, V., Baka, M., et al. (2020). The complex effect of food matrix fat content on thermal inactivation of listeria monocytogenes: case study in emulsion and gelled emulsion model systems. Front. Microbiol. 10:3149. doi: 10.3389/ fmicb.2019.03149

Vojdani, J. D., Beuchat, L. R., and Tauxe, R. V. (2008). Juice-associated outbreaks of human illness in the United States, 1995 through 2005. J. Food Prot. 71, 356-364. doi: 10.4315/0362-028X-71.2.356

Wesche, A. M., Gurtler, J. B., Marks, B. P., and Ryser, E. T. (2009). Stress, sublethal injury, resuscitation, and virulence of bacterial foodborne pathogens. J. Food Prot. 72, 1121-1138. doi: 10.4315/0362-028x-72.5.1121

Wuytack, E. Y., Phuong, L. D. T., Aertsen, A., Reyns, K. M. F., Marquenie, D., De Ketelaere, B., et al. (2003). Comparison of sublethal injury induced in salmonella enterica serovar Typhimurium by heat and by different nonthermal treatments. J. Food Prot. 66, 31-37. doi: 10.4315/0362-028X-66.1.31

Yousef, A. E., and Courtney, P. D. (2003). "Basics of stress adaptation and implications in new-generation foods," in Microbial Stress Adaptation and Food Safety. eds. A. E. Yousef and V. K. Juneja (Boca Raton, FL: CRC Press), 1-30.

Zhao, T., Doyle, M. P., and Besser, R. E. (1993). Fate of enterohemorrhagic Escherichia coli O157: $\mathrm{H} 7$ in apple cider with and without preservatives. Appl. Environ. Microbiol. 59, 2526-2530.

Zurera-Cosano, G., Otero-Carballeira, A., Carrasco-Jiménez, E., Pérez-Rodríguez, F., and Valero-Díaz, A. (2011). Informe del Comité Científico de la Agencia Española de Seguridad Alimentaria y Nutrición (AESAN) en relación al efecto de la reducción de la sal en la seguridad microbiológica de los productos cárnicos curados. Rev. Com. Científico AESAN 13, 59-87.

Conflict of Interest: The authors declare that the research was conducted in the absence of any commercial or financial relationships that could be construed as a potential conflict of interest.

Publisher's Note: All claims expressed in this article are solely those of the authors and do not necessarily represent those of their affiliated organizations, or those of the publisher, the editors and the reviewers. Any product that may be evaluated in this article, or claim that may be made by its manufacturer, is not guaranteed or endorsed by the publisher.

Copyright (c) 2021 Clemente-Carazo, Leal, Huertas, Garre, Palop and Periago. This is an open-access article distributed under the terms of the Creative Commons Attribution License (CC BY). The use, distribution or reproduction in other forums is permitted, provided the original author(s) and the copyright owner(s) are credited and that the original publication in this journal is cited, in accordance with accepted academic practice. No use, distribution or reproduction is permitted which does not comply with these terms. 